\title{
Risk Factors and Incidence of Ongoing Symptomatic Covid-19: A Longitudinal Study of 192 Patients from March 2020 to March 2021 in a General Medicine Clinic in Toledo (Spain)
}

\section{Turabian JL*}

Specialist in Family and Community Medicine, Regional Health Service of Castilla la Mancha (SESCAM), Spain

*Corresponding author: Jose Luis Turabian, Health Center Santa Maria de Benquerencia, Regional Health Service of Castilla la Mancha (SESCAM), Toledo, Spain, Email: jturabianf@ hotmail.com

\section{Research Article \\ Volume 5 Issue 3}

Received Date: August 18, 2021

Published Date: September 16, 2021

DOI: $10.23880 /$ eij-16000201

\section{Abstract}

Background: Although many of COVID-19 patients recover without complications, some have a prolonged illness, but the evidence for their characteristics is limited.

Objective: To compare the clinical-epidemiological characteristics of patients with COVID-19 who develop Ongoing Symptomatic COVID-19 (persistent symptoms and/or delayed or long-term complications beyond 4 weeks from the onset of symptoms) vs. not developing it, in medicine general.

Methodology: An observational, longitudinal and prospective study of COVID-19 patients in a family medicine office in Toledo (Spain) was carried out from March 15, 2020 to March 31, 2021.

Results: During the study period, 192 patients were included, 33 with Ongoing Symptomatic COVID-19, which represents an incidence of $17 \%$. 58\% were women vs. 52\% in COVID-19 cured before 4 weeks. The age was 54 vs. 39 years in the COVID group cured before 4 weeks ( $\mathrm{p}<.00001)$. The variables that showed a statistically significant relative risk were: some type of labor specialization, moderate-severe severity, hospitalization in the acute phase, readmission after discharge (all with high risk), chronic diseases presence with moderate risk, and presence of respiratory symptoms in the acute phase with low risk.

The following variables were statistically significant, as a protective factor: age $=<45$ years, being asymptomatic in the acute phase, and presenting ENT symptoms in the acute phase.

Conclusion: In the context of general medicine in Toledo (Spain), the incidence during one year of Ongoing Symptomatic COVID-19 was moderate, affecting older adult patients with severe respiratory symptoms during the acute phase. The management of these patients may require integrated approaches rather than specific organs or diseases, and that is the place of the General Practitioner in healthcare services.

Keywords: COVID-19; SARS-CoV-2; Post-COVID-19 Condition; General Practice; Epidemiology; Symptoms; Cohort Studies; Risk Factors 


\section{Epidemiology International Journal}

Abbreviations: COVID-19: Coronavirus Disease 2019; WHO: World Health Organization; NICE: National Institute for Excellence in Health and Care; RR: Relative Risk; PCR: Polymerase Chain Reaction.

\section{Introduction}

After more than a year, with more than 122 million COVID-19 cases reported globally, and after passing a second and third wave, the long-term consequences of Coronavirus disease 2019 (COVID-19) are an urgent public health priority $[1,2]$. Much has been learned about the disease. But among the questions that remain open is the most important: how many people who have been infected will suffer symptoms and lasting health problems?.

Like many other diseases, COVID-19 can cause longlasting problems. A large American study found similar effects for both hospitalized and non-hospitalized people. Among the adults who were not hospitalized, 1 in 10 had continuous symptoms 12 weeks after a positive test [3]. UK estimates from a weighted sample of 9,063 people with COVID-19 suggest that $22 \%$ of people still have symptoms 5 weeks after initial infection and $10 \%$ still have symptoms at 12 weeks [4]. The World Health Organization (WHO) estimates that $10 \%$ of COVID-19 survivors, including hospitalized and non-hospitalized individuals, have persistent problems 12 weeks after infection [5].

These people who have had the virus and experience symptoms that continue beyond the acute phase have been referred to by groups of patients as "Long COVID". It has been suggested that implementing well-functioning patient registries and other surveillance systems, creating patient cohorts, and monitoring those affected are means of supporting the research that is so critical to understanding and treating Long COVID [6-11]. Existing evidence suggests large variations in estimates of the prevalence and incidence of post-COVID syndrome due to differences in study populations, recruitment methods, follow-up periods, and sample sizes [12].

It has been estimated that up to $30 \%$ of the COVID-19 health burden could be due to COVID-19-induced disability, not death. Much more needs to be done to improve these estimates so that effective action can be taken. Treatment services for the long-term consequences of COVID-19 must already be urgently absorbed by health and care systems. Addressing this requires a much clearer picture of the burden of disease than currently exists. To be prepared for long-term COVID-19 problems, all health systems will need to monitor "recovered" patients, assess the prevalence of persistent symptoms, and seek ways to help these patients [13].
In this context, our objective was:

- To estimate the incidence of Ongoing Symptomatic COVID-19 (persistent symptoms and/or delayed or long-term complications beyond 4 weeks from the onset of symptoms);

- Compare the clinical-epidemiological characteristics of patients with Ongoing Symptomatic COVID-19 vs those who do not develop it; and

- To analyze some of the possible risk factors for contracting Ongoing Symptomatic COVID-19; All this in a general medicine consultation.

\section{Material and Methods}

\section{Design and Emplacement}

An observational, longitudinal and prospective study of COVID-19 patients was carried out from March 15, 2020 to March 31, 2021, in a family medicine office in the Health Center Santa Maria de Benquerencia, Toledo (Spain), which has a list of 2,000 patients $>14$ years of age (in Spain, general practitioners -GPs- care for people $>14$ years of age, except for exceptions requested by the child's family and accepted by the GP).

\section{Outcome of Interest}

The outcome of interest was to study some of the possible risk factors for contracting Ongoing Symptomatic COVID-19, a syndrome characterized by persistent symptoms and/or late or long-term complications beyond 4 weeks from the onset of symptoms [14]. Long COVID or Ongoing Symptomatic COVID-19 is not a condition, and the National Institute for Excellence in Health and Care (NICE) defines it as "signs and symptoms of COVID-19 from 4 to 12 weeks" [15].

In this sense, the variables collected were compared by calculating the relative risk (RR) as the Incidence among the exposed population/Incidence among the population not exposed to possible risk factors, in the Ongoing Symptomatic COVID-19 patients and those who were not ill 4 weeks after. RR expresses to the clinician the excess risk that a patient has for being exposed to the risk factor, and also serves to identify people at high risk, but does not measure the probability that someone with the risk factors will acquire the disease. The RR was interpreted as follows [16]:

- From 0 to 0.5 protection factor effectively

- From 0.6.0.8 true benefits

- From 0.9 to 1.1 not significant

- From 1.2 to 1.6 weak risk

- From 1.7 to 2.5 moderate risk

- More than 2.5 strong risk 


\section{Epidemiology International Journal}

\section{Diagnosis of COVID-19}

The diagnosis was performed with oropharyngeal Polymerase Chain Reaction (PCR) or antigen test. Since the beginning of the pandemic in mid-March 2020, PCR tests were only performed in the hospital context until mid-May 2020 , when they began to be performed in general medicine as well. In mid-December 2020, rapid antigen tests began for symptomatic patients with less than 5 days of evolution. The PCR tests were performed both in symptomatic patients and in asymptomatic contacts. A symptomatic confirmed case with active infection was considered to be any person with a clinical picture of sudden onset acute respiratory infection of any severity that occurs, among others, with fever, cough or feeling of shortness of breath. Other symptoms such as odynophagia, anosmia, ageusia, muscle pain, diarrhea, chest pain or headache, among others, were also considered symptoms of suspected SARS-CoV-2 infection according to clinical criteria; and a positive PCR test [17].

\section{Diagnosis of Ongoing Symptomatic COVID-19}

It was defined as a syndrome characterized by persistent symptoms and/or late or long-term complications beyond 4 weeks from the onset of symptoms $[14,15,18]$. The COVID-19 case series, whose results are compared with patients with COVID-19 symptoms resolved within 4 weeks, was previously published [19].

\section{Collected Variables}

The following variables were collected: age; sex; symptoms; chronic diseases (defined as "any alteration or deviation from normal that has one or more of the following characteristics: is permanent, leaves residual impairment, is caused by a non-reversible pathological alteration, requires special training of the patient for rehabilitation, and/or can be expected to require a long period of control, observation or treatment" [20], classified according to the International Statistical Classification of Diseases and Health-Related Problems, CD-10 Version: 2019 [21]; social-occupancy class (according to the Registrar General's classification of occupations and social status code) [22,23]; complex family and low income household based on the genogram and in the experience of the general practitioner for their continuity of care and knowledge of the family (genogram was a schematic model of the structure and processes of a family, which included the family structure, life cycle and family relational patterns. It was understood that "complex" genograms present families with psychosocial problems)
[24-27]; ethnic minority; family size (number of members); and severity of the disease (mild cases: clinical symptoms are mild and no manifestation of pneumonia can be found on images; moderate cases: with symptoms such as fever and respiratory tract symptoms, and the manifestation of pneumonia can be seen on the imaging tests; and severe cases: respiratory distress, respiratory rate $\geq 30$ breaths/ min., pulse oxygen saturation $\leq 93 \%$ with room air at rest, arterial partial pressure of oxygen/oxygen concentration $\leq 300 \mathrm{mmHg}$.) [28]. To simplify comparison, moderate and severe cases were counted together.

\section{Sample}

All patients who met the criteria for Ongoing Symptomatic COVID-19 from March 15, 2020 to March 31, 2021 were included, and they were seen in the consultation object of the study and their medical documentation was available.

\section{Statistical Analysis}

The bivariate comparisons were performed using the Chi Square test (X2) with Yates correction or Fisher Exact Test when necessary, (according to the number the expected cell totals) for percentages, and the Student $t$ test for the mean.

\section{Results}

During the study period (1 year), 192 patients were included, 33 with Ongoing Symptomatic COVID-19, which represents an incidence of $17 \%$. 58\% were women vs. $52 \%$ with COVID-19 cured before 4 weeks $(\mathrm{X} 2=0.395$. $\mathrm{P}=$ .529658. NS); Age in years (Arithmetic mean + - Standard deviation) was $54.21+-13.71$ vs. $39.36+-17.81$ in the COVID group cured before 4 weeks $(\mathrm{t}=4.49641 ; \mathrm{P}<.00001$ Significant at $\mathrm{p}<.05$.). The variables that showed a significant RR were: some type of labor specialization, moderate-severe severity, hospitalization in the acute phase, readmission after discharge (all with strong risk), chronic diseases presence with moderate risk, and presence of respiratory symptoms (cough , dyspnea, chest pain) in the acute phase with weak risk. The following variables were statistically significant as a protective factor: age $=<45$ years, being asymptomatic in the acute phase, and presenting ENT symptoms (anosmia/ ageusia, odynophagia, rhinorrhea, dryness and pharyngeal mucus) in the acute phase, all rated as an effective protection factor (Tables 1-3). 
Epidemiology International Journal

\begin{tabular}{|c|c|c|c|c|}
\hline Variables & $\begin{array}{c}\text { Ongoing } \\
\text { Symptomatic } \\
\text { Covid-19 } \mathrm{N}=33\end{array}$ & $\begin{array}{c}\text { Covid-19 } \\
\text { Cured Before } \\
4 \text { Weeks Of } \\
\text { Evolution } \\
\text { N=159 } \\
\end{array}$ & Statistical Significance & Relative Risk \\
\hline $\begin{array}{c}\text { Age in years (Arithmetic } \\
\text { mean }+- \text { Standard deviation) }\end{array}$ & $54.21+-13.71$ & $39.36+-17.81$ & $\begin{array}{c}\mathrm{t}=4.49641 . \mathrm{p}=<.00001 \\
\text { Significant at } \mathrm{p}<.05\end{array}$ & - \\
\hline$>=65$ years & $7(21)$ & $15(9)$ & $\begin{array}{c}\mathrm{X} 2 \text { with Yates correction }= \\
2.666 . \mathrm{p}=.102514 . \mathrm{NS} \\
\end{array}$ & $\begin{array}{c}\mathrm{RR}=2.08(95 \% \mathrm{CI}): 0.86, \\
\text { 5.02) Strong risk }\end{array}$ \\
\hline$=<45$ years & $8(24)$ & $104(65)$ & $\begin{array}{c}\mathrm{X} 2=19.0542 . \mathrm{p}=.000013 . \\
\text { Significant at } \mathrm{p}<.05 .\end{array}$ & $\begin{array}{l}\mathrm{RR}=0.23(\mathrm{CI} 95 \%: 0.46,0.12) \\
\text { Effective protection factor }\end{array}$ \\
\hline$=<18$ years & 0 & $16(10)$ & $\begin{array}{c}\text { Fisher exact test }= \\
0.0788 . \text { NS. }\end{array}$ & $\begin{array}{l}\mathrm{RR}=0 \text { (CI 95\%: Infinity, } 0) \\
\text { Effective protection factor }\end{array}$ \\
\hline Women & $19(58)$ & $82(52)$ & $\begin{array}{c}\mathrm{X} 2=0.395 . \mathrm{p}=.529658 . \\
\text { NS. }\end{array}$ & $\begin{array}{c}\mathrm{RR}=1.22(\mathrm{CI} 95 \%: 0.5,2.9) \\
\text { Weak risk }\end{array}$ \\
\hline Men & $14(42)$ & $77(48)$ & $\begin{array}{c}\mathrm{X} 2=0.395 . \mathrm{p}=.529658 . \\
\mathrm{NS}\end{array}$ & $\begin{array}{c}\mathrm{RR}=0.82 \text { (CI 95\%: 11.85, } \\
-18.71) \\
\text { Certain benefit }\end{array}$ \\
\hline Family with $>=4$ members & $5(15)$ & $33(21)$ & $\begin{array}{c}\mathrm{X} 2=0.5405 . \mathrm{p}=.462233 . \\
\text { NS. }\end{array}$ & $\begin{array}{c}\mathrm{RR}=0.72(\mathrm{CI} 95 \%: 2.61,0.29) \\
\text { Certain benefit }\end{array}$ \\
\hline Asymptomatic & $1(3)$ & $35(22)$ & $\begin{array}{l}\mathrm{X} 2=6.4637 . \mathrm{p}=.01101 . \\
\text { Significant at } \mathrm{p}<.05 .\end{array}$ & $\begin{array}{c}\mathrm{RR}=0.14(\mathrm{CI} 95 \%: 0.75,0.03) \\
\text { Effective protection factor }\end{array}$ \\
\hline $\begin{array}{c}\text { Social-occupancy class of } \\
\text { patients (people with some } \\
\text { type of labour specialization) }\end{array}$ & $17(51)$ & $48(30)$ & $\begin{array}{l}\mathrm{X} 2=5.5505 . \mathrm{p}=.018475 \\
\text { Significant at } \mathrm{p}<.05\end{array}$ & $\begin{array}{c}\mathrm{RR}=2.08(\mathrm{CI} 95 \%: 1.07,4.06) \\
\text { Strong risk }\end{array}$ \\
\hline Sick leave in acute period & $15(45)$ & $47(30)$ & $\begin{array}{c}\mathrm{X} 2=3.1578 . \mathrm{p}=.075564 . \\
\text { NS. }\end{array}$ & $\begin{array}{c}\mathrm{RR}=1.75(\mathrm{CI} 95 \%: 0.87,3.52) \\
\text { Moderate risk }\end{array}$ \\
\hline Students & $1(3)$ & $24(15)$ & $\begin{array}{l}\mathrm{X} 2 \text { with Yates correction= } \\
\text { 2.5274. } \mathrm{p}=.111881 . \mathrm{NS} .\end{array}$ & $\begin{array}{c}\mathrm{RR}=0.21(\mathrm{CI} 95 \%: 1.44,0.03) \\
\text { Weak risk }\end{array}$ \\
\hline Ethnic minority & $9(27)$ & $31(19)$ & $\begin{array}{c}\mathrm{X} 2=1.0019 . \mathrm{p}=.316861 . \\
\text { NS. }\end{array}$ & $\begin{array}{c}\mathrm{RR}=1.42(\mathrm{CI} 95 \%: 0.58,3.47) \\
\text { Weak risk }\end{array}$ \\
\hline Low income household & $4(12)$ & $13(8)$ & $\begin{array}{c}\text { Fisher exact test }=0.5003 . \\
\text { NS. }\end{array}$ & $\begin{array}{c}\mathrm{RR}=1.42 \text { (CI 95: 0.24, 8.27) } \\
\text { Weak risk }\end{array}$ \\
\hline Complex family & 0 & $8(5)$ & $\begin{array}{c}\text { Fisher exact test }=0.355 . \\
\text { NS. }\end{array}$ & $\begin{array}{l}\text { RR=0 (CI 95\%: Infinity. 0) } \\
\text { Effective protection factor }\end{array}$ \\
\hline Chronic diseases presence & $18(54)$ & $46(29)$ & $\begin{array}{l}\mathrm{X} 2=8.0686 . \mathrm{p}=.004504 . \\
\text { Significant at } \mathrm{p}<.05 .\end{array}$ & $\begin{array}{c}\mathrm{RR}=2.4(\mathrm{CI} 95 \%: 1.25,4.6) \\
\text { Moderate risk }\end{array}$ \\
\hline Moderate-severe Severity & $17(51)$ & $5(3)$ & $\begin{array}{c}\text { Fisher exact test }< \\
0.00001 . \text { Significant at } \mathrm{p} \\
<.05 .\end{array}$ & $\begin{array}{c}\mathrm{RR}=8.21 \text { (CI 95\%: 4.78, } \\
14.09) \\
\text { Strong risk } \\
\end{array}$ \\
\hline $\begin{array}{l}\text { Hospitalization in acute } \\
\text { phase }\end{array}$ & $14(42)$ & $4(2)$ & $\begin{array}{c}\text { Fisher exact test }< \\
0.00001 . \text { Significant at } \mathrm{p} \\
<.05 .\end{array}$ & $\begin{array}{c}\mathrm{RR}=7.12 \text { (CI 95\%: 4.05, } \\
12.51) \\
\text { Strong risk } \\
\end{array}$ \\
\hline Readmission after discharge & $2(6)$ & 0 & $\begin{array}{c}\text { Fisher exact test }=0.0288 \\
\text { Significant at } \mathrm{p}<.05\end{array}$ & $\begin{array}{c}\mathrm{RR}=6.13(\mathrm{CI} 95 \%: 1.2,31.29) \\
\text { Strong risk }\end{array}$ \\
\hline
\end{tabular}

( ): Denotes percentages

CI: Confidence interval

NS: Not significant at $\mathrm{p}<.05$.

Table 1: Comparison of Selected Variables Between Ongoing Symptomatic Covid-19 and Covid-19 Cured before 4 Weeks of Evolution. 


\section{Epidemiology International Journal}

\begin{tabular}{|c|c|c|c|c|}
\hline $\begin{array}{c}\text { Symptoms In The Acute } \\
\text { Phase* }\end{array}$ & $\begin{array}{c}\text { Ongoing } \\
\text { Symptomatic } \\
\text { Covid-19 } \mathrm{N}=33 \\
\end{array}$ & $\begin{array}{c}\text { Covid-19 Cured } \\
\text { Before } 4 \text { Weeks Of } \\
\text { Evolution } N=159 \\
\end{array}$ & Statistical Significance & Relative Risk \\
\hline $\begin{array}{c}\text { General (Discomfort, Asthenia, } \\
\text { Myalgia, Fever) }\end{array}$ & $45(33)$ & $128(36)$ & $\begin{array}{c}\mathrm{X} 2=0.4075 . \mathrm{p}=.523221 . \\
\text { NS. }\end{array}$ & $\begin{array}{c}\mathrm{RR}=0.91(\mathrm{CI} 95 \%: \\
1.29,0.64) \\
\text { Not significant }\end{array}$ \\
\hline $\begin{array}{l}\text { Respiratory (Cough, Dyspnea, } \\
\text { Chest pain) }\end{array}$ & $45(33)$ & $82(23)$ & $\begin{array}{l}\mathrm{X} 2=4.9991 . \mathrm{p}=.025361 . \\
\text { Significant at } \mathrm{p}<.05\end{array}$ & $\begin{array}{c}\mathrm{RR}=1.41(\mathrm{CI} 95 \%: \\
1.03,1.94) \\
\text { Weak risk }\end{array}$ \\
\hline $\begin{array}{c}\text { ENT (Anosmia / Ageusia, } \\
\text { Odynophagia, Rhinorrhea, } \\
\text { Pharyngeal dryness and } \\
\text { mucus) }\end{array}$ & $15(11)$ & $79(22)$ & $\begin{array}{l}\mathrm{X} 2=8.0604 . \mathrm{p}=.004524 . \\
\text { Significant at } \mathrm{p}<.05 .\end{array}$ & $\begin{array}{c}\mathrm{RR}=0.52 \text { (CI } 95 \%: \\
0.83,0.32) \\
\text { Effective protection } \\
\text { factor }\end{array}$ \\
\hline $\begin{array}{c}\text { Digestive (Anorexia, Nausea / } \\
\text { Vomiting, Diarrhea, Abdominal } \\
\text { pain) }\end{array}$ & $12(8)$ & $26(7)$ & $\begin{array}{c}\mathrm{X} 2=0.2982 . \mathrm{p}=.585037 . \\
\text { NS. }\end{array}$ & $\begin{array}{c}\mathrm{RR}=1.15(\mathrm{CI} 95 \%: \\
0.54,2.46) \\
\text { Not significant } \\
\end{array}$ \\
\hline $\begin{array}{c}\text { Neurological (Headache, } \\
\text { Dizziness, Mental confusion ) }\end{array}$ & $13(9)$ & $30(8)$ & $\begin{array}{c}\mathrm{X} 2=0.1427 . \mathrm{p}=.705593 . \\
\text { NS. }\end{array}$ & $\begin{array}{c}\mathrm{RR}=1.1 \text { (CI 95\%: } 0.43, \\
\text { 2.8) Not significant }\end{array}$ \\
\hline Psychiatric (Anxiety, Insomnia) & $7(5)$ & $10(3)$ & $\begin{array}{c}\mathrm{X} 2 \text { with Yates correction= } \\
0.9618 . \mathrm{p}=.326732 . \mathrm{NS} .\end{array}$ & $\begin{array}{c}\mathrm{RR}=1.51(\mathrm{CI} 95 \%: \\
0.66,3.44) \\
\text { Weak risk }\end{array}$ \\
\hline $\begin{array}{l}\text { Skin (Chilblains, Flictenas, } \\
\text { Rash) }\end{array}$ & $1(1)$ & $2(0.5)$ & Fisher exact test $=1$. NS. & $\begin{array}{c}\mathrm{RR}=1.2 \text { (CI 95\%: 0.52, } \\
2.75 \text { ) } \\
\text { Weak risk }\end{array}$ \\
\hline Eyes (Eye pain, Eye pruritus) & 0 & $2(0.5)$ & Fisher exact test $=1$. NS. & $\begin{array}{c}\mathrm{RR}=0 \text { (CI 95\%: } \\
\text { infinity, 0) } \\
\text { Effective protection } \\
\text { factor }\end{array}$ \\
\hline Total symptoms* & $138(100)$ & $359(100)$ & & - \\
\hline
\end{tabular}

( ): Denotes percentages

* Patients could have more than one symptom. The percentages are over the total of symptoms

CI: Confidence interval

NS: Not significant at $\mathrm{p}<.05$.

Table 2: Comparison of Symptoms in the Acute Phase Between Ongoing Symptomatic Covid-19 and Covid-19 Cured before 4 Weeks of Evolution.

\begin{tabular}{|c|c|c|c|c|}
\hline $\begin{array}{l}\text { Chronic Diseases* } \\
\text { According To Who, } \\
\text { Icd-10 Groups }\end{array}$ & $\begin{array}{l}\text { Ongoing Symptomatic } \\
\text { Covid-19 N=33 }\end{array}$ & $\begin{array}{l}\text { Covid-19 Cured } \\
\text { Before } 4 \text { Weeks Of } \\
\text { Evolution } N=159\end{array}$ & $\begin{array}{c}\text { Statistical } \\
\text { Significance }\end{array}$ & Relative Risk \\
\hline -II Neoplasms & $3(4)$ & $4(4)$ & $\begin{array}{l}\text { Fisher exact } \\
\text { test=1. NS. }\end{array}$ & $\begin{array}{c}\mathrm{RR}=1.11 \text { (CI 95\%: 0.36, 3.46) } \\
\text { Not significant }\end{array}$ \\
\hline -IV Endocrine & $15(21)$ & $23(21)$ & $\begin{array}{l}\mathrm{X} 2=0.0069 . \mathrm{p}= \\
.933648 . \mathrm{NS}\end{array}$ & $\begin{array}{c}\mathrm{RR}=1.02(\mathrm{CI} 95 \%: 0.69,1.5) \\
\text { Not significant }\end{array}$ \\
\hline -V Mental & $7(10)$ & $11(10)$ & $\begin{array}{c}\mathrm{X} 2=0 . \mathrm{p}=1 . \\
\text { NS. }\end{array}$ & $\begin{array}{c}\mathrm{RR}=1(\mathrm{CI} 95 \%: 1,1) \\
\text { Not significant }\end{array}$ \\
\hline $\begin{array}{l}\text {-VI-VIII Nervous and } \\
\text { Senses } \\
\end{array}$ & $7(10)$ & $8(7)$ & $\begin{array}{l}\mathrm{X} 2=0.4165 . \mathrm{p}= \\
.518674 . \mathrm{NS}\end{array}$ & $\begin{array}{c}\mathrm{RR}=1.22 \text { (IC 95\%: } 0.43,3.5 \text { ) } \\
\text { Weak risk }\end{array}$ \\
\hline -IX Circulatory system & $13(19)$ & $19(17)$ & $\begin{array}{l}\mathrm{X} 2=0.0494 . \mathrm{p}= \\
.824182 . \mathrm{NS}\end{array}$ & $\begin{array}{c}\mathrm{RR}=1.06 \text { (CI 95\%: 0, 320.1) } \\
\text { Not significant }\end{array}$ \\
\hline -X Respiratory system & $3(4)$ & $10(9)$ & $\begin{array}{l}\mathrm{X} 2=1.4741 . \mathrm{p}= \\
.224701 . \mathrm{NS}\end{array}$ & $\begin{array}{c}\mathrm{RR}=0.58(\mathrm{CI} 95 \%: 1.85,0.18) \\
\text { Effective protection factor }\end{array}$ \\
\hline
\end{tabular}




\section{Epidemiology International Journal}

\begin{tabular}{|c|c|c|c|c|}
\hline -XI Digestive system & $5(7)$ & $9(8)$ & $\begin{array}{c}\text { X2=0.0644. }= \\
\text { 799708. NS. }\end{array}$ & $\begin{array}{c}\text { RR= 0.91 (CI 95\%: 431.52, 0) } \\
\text { Not significant }\end{array}$ \\
\hline -XII Diseases of the skin & $2(3)$ & $2(2)$ & $\begin{array}{c}\text { Fisher exact } \\
\text { test=0.6428. } \\
\text { NS. }\end{array}$ & $\begin{array}{c}\text { RR= } 1.29 \text { (CI 95\%: 0, 5286.73) } \\
\text { Weak risk }\end{array}$ \\
\hline -XIII Musculo-skeletal & $9(13)$ & $15(14)$ & $\begin{array}{c}\text { X2=0.0225. p= } \\
.880824 . \mathrm{NS} .\end{array}$ & $\begin{array}{c}\text { RR= 0.96 (CI 95\%: 3.01, o.31) } \\
\text { Not significant }\end{array}$ \\
\hline -XIV Genitourinary & $6(9)$ & $9(8)$ & $\begin{array}{c}\text { X2=0.0085. }= \\
.92654 . \mathrm{NS} .\end{array}$ & $\begin{array}{c}\text { RR= 1.03 (CI 95\%: 0.75, 1.42) } \\
\text { Not significant }\end{array}$ \\
\hline $\begin{array}{c}\text { TOTAL chronic } \\
\text { diseases* }\end{array}$ & $70(100)$ & $110(100)$ & - & - \\
\hline
\end{tabular}

(): Denotes percentages

* Patients could have more than one chronic disease. The percentages are over the total of chronic diseases

CI: Confidence interval

NS: Not significant at $\mathrm{p}<.05$.

Table 3: Comparison of Chronic Diseases Between Ongoing Symptomatic Covid-19 and Covid-19 Cured Before 4 Weeks of Evolution.

\section{Discussion}

The GP is in a rare, special and specific position in the health system, which allows him to combine the clinical tasks of integral or holistic diagnosis and treatment on individuals and families, with the epidemiological and public health tasks on families and communities. In addition both roles of the GP feed each other [29-31]. Registries in general practice are key sources for morbidity estimates, especially if all people are registered in a general practice and if the general practitioner is the gatekeeper of health care; so, diagnoses from medical specialists and other health care providers will also be known by the general practitioner. The collection of data in General Medicine is cumulative and continuous. The path of all patients begins and ends with the family doctor [32].

COVID-19 is a viral infection that can cause a variety of respiratory, gastrointestinal, and vascular symptoms. The acute phase of the disease generally lasts no more than 2 to 3 weeks. However, there is growing evidence that a proportion of COVID-19 patients experience prolonged convalescence and continue to have symptoms that last for several months after the initial infection [33]. There is a misconception that all COVID-19 patients can recover within two weeks; this is not always the case. The long-term consequences of COVID-19 infection are not well understood [34].

The difficulties of studying Long COVID (a term first coined by a patient on Twitter), begins with the definitions. COVID-19 'post-acute', the umbrella term adopted by the $\mathrm{NIH}$ to capture prolonged health abnormalities in people who have been infected with SARS-CoV-2, also covered a wide space, including the effects of potentially overlapping sequelae, such as the syndrome associated with treatment in an intensive care unit $[5,18]$.

\section{Incidence of Ongoing Symptomatic COVID-19}

The most conservative estimates speak of $10 \%$ of symptomatic cases, but others raise this figure even to $20 \%$. In fact, between $10 \%$ and $80 \%$ of all people infected with COVID-19 have been reported to experience symptoms months later or they had long-term effects [35-46]. We found an incidence of $17 \%$.

\section{Symptoms of Ongoing Symptomatic COVID-19}

COVID survivors report a wide range of highly heterogeneous and overlapping long-term symptoms including generalized chest and muscle pain, fatigue, shortness of breath, wheezing, exercise intolerance, inappropriate tachycardia, gastrointestinal disturbances, hair loss, headache, dysfunction cognitive, dysautonomia, "mental fog", mood disorders, and anxiety disorders and insomnia. The mechanisms involved affect multiple systems and include persistent inflammation, thrombosis, and autoimmunity [6,13,39,47-50].

In a meta-analysis [47], researchers identified nearly 2,000 studies that addressed persistent symptoms after COVID-19; Forty-five studies, with a total of approximately 10,000 patients and 84 discrete symptoms, were considered suitable for analysis. The studies were highly heterogeneous, including wide variation in the severity and nature of the original infections. The most common symptoms were fatigue ( $40 \%$ of patients), shortness of breath (36\%), anosmia (24\%), anxiety (22\%), persistent cough (17\%), ageusia (16\%), and depression (15\%). 


\section{Epidemiology International Journal}

Long COVID is likely to involve multiple types of conditions with different causes: autoantibodies, mutations affecting type I interferons, viral reservoirs, persistent fragments of viral RNA or proteins, etc [51]. But so far there is still limited information on the true scope and scale of this post-viral problem. The underlying biology is also unclear [5].

The frequency of symptoms in the Ongoing Symptomatic COVID-19 in the general population often makes its evaluation difficult [52]. In addition, it has been reported that certainty of being infected with COVID-19 and anxiety predicted $27 \%$ of the variation in reporting of symptoms similar to COVID-19. Women had higher levels of anxiety and stress, and reported more COVID-like symptoms than men; that is, cognitive and emotional factors can create a nocebo effect (whose underlying causes are negative expectations and / or negative previous experiences) and which is greater in women [53]. Initial experience suggests that symptoms may be out of proportion to observable organ dysfunction [54]. On the other hand, there is probably a selection bias in many of the initial reports: common symptoms (fatigue, weakness, insomnia, dyspnea, and mental confusion) are difficult to quantify. Fatigue compared to what? When it comes to cognition, the past 12 months have not been an easy time to focus on a task. And "you can count on the fingers of both hands the number of people who in the clinic report that they sleep well" [55]. However, patients may report that "they were ashamed to talk about their complaints at the doctor's appointment", and that "some of their complaints were dismissed as psychosomatic" [56].

\section{Risk Factors for Ongoing Symptomatic COVID-19}

Some pre-existing conditions and risk factors are predictors of acute covid-19 outcomes, such as admission to the intensive care unit and mortality, but the epidemiology of Long COVID has been less well defined $[57,58]$. No baseline clinical characteristics behaved as independent predictors of the development of Long COVID [35,56]. All age groups are seen affected. But, we found the mean age was significantly higher in the Ongoing Symptomatic COVID-19 vs. COVID-19 cured before 4 weeks $(54.21+-13.71$ vs. $39.36+-17.81$ years).

Ongoing Symptomatic COVID-19 occurs regardless of the severity of the infection (from asymptomatic to severe) and health status. However, several studies show that patients who have been hospitalized for their COVID-19 disease are significantly more likely to experience symptoms 8 or more weeks after discharge (more than 50\%) [56-60]; we also found a "strong" and statistically significant RR for the greatest severity, hospitalization in the acute phase, and readmission after discharge.
The following risk factors for Long-COVID have been reported: age, especially over 50 years, female gender, obesity, and asthma [38]. On the other hand, more than 5 symptoms in the first week have been reported to augur Long COVID-19 [52]. RRs were higher in ethnic minority groups than the white population [12]. In our study, 58\% were women vs. 52\% in COVID-19 cured before 4 weeks, chronic diseases presence showed a moderate risk, and the presence of respiratory symptoms (cough, dyspnea, chest pain) in the acute phase showed a weak risk. In addition, age $=<45$ years and being asymptomatic in the acute phase were statistically significant as a protective factor.

\section{Limitations of the Study}

Although registries in general practice are key sources for morbidity estimates (especially if all people are registered in a general practice and if the GP is the gatekeeper of health care and diagnoses from medical specialists and other health care providers they are also known by the GP), number of cases presented probably indicate a "minimal incidence", and there is the possibility of greatly underestimating the real incidence, since there are many reasons why patients with persistent symptoms may not attend the health service, such as mild symptoms, poor health or access to medical care, and the risk of reinfection when visiting a healthcare facility during the COVID-19 pandemic [61].

\section{Conclusion}

In the context of general medicine in Toledo (Spain), this study confirms that the incidence of Ongoing Symptomatic COVID-19 during 1 year was moderate-high (17\%), with variable and complex symptoms that affect different organs and systems, with elderly patients as mainly affected that were severe ill in the acute phase due to respiratory symptoms. The diagnosis, treatment and prevention of postcovid syndrome may require integrated approaches rather than specific organs or diseases, and that is the place of the GP.

\section{References}

1. Coronavirus COVID-19 Global Cases by the Center for Systems Science and Engineering (CSSE) at Johns Hopkins. The Center for Systems Science and Engineering (CSSE) at JHU.

2. Kondratiuk AL, Pillay TD, Kon OM, Lalvani A (2021) A conceptual framework to accelerate the clinical impact of evolving research into long COVID. Lancet Infect Dis 21(6): 756-757.

3. Briggs A, Vassall A (2021) Count the cost of disability caused by COVID-19. Focusing only on cases and deaths 
hides the pandemic's lasting health burden on people, societies and economies. Nature 593: 502-505.

4. Office for National Statistics (2021) Updated estimates of the prevalence of long COVID symptoms.

5. Mullard A (2021) Long COVID's long R\&D agenda. Nat Rev Drug Discov 20: 329-331.

6. WHO (2021) In the wake of the pandemic: preparing for Long COVID.

7. Alger HM, Williams JH, Walchok JG, Bolles M, Fonarow GC, et al. (2020) Role of data registries in the time of COVID-19. Circ Cardiovasc Qual Outcomes 13: 006766.

8. Nanda S, Toussaint L, Vincent A, Fischer KM, Hurt R, et al. (2021) A Midwest COVID-19 Cohort for the Evaluation of Multimorbidity and Adverse Outcomes from COVID-19. J Prim Care Community Health 12: 1-6.

9. National Institutes of Health (2021) List of Registries.

10. Gliklich R, Dreyer N, Leavy M (2014) Registries for Evaluating Patient Outcomes: A User's Guide. $3^{\text {rd }}$ (Edn.), Two volumes. (Prepared by the Outcome DEcIDE Center [Outcome Sciences, Inc., a Quintiles company] under Contract No. 290200500351 T07.) AHRQ Publication No. 13(14)-EHC111. Rockville, MD: Agency for Healthcare Research and Quality.

11. Workman TA (2013) Engaging patients in information sharing and data collection: the role of patient-powered registries and research networks. Agency for Healthcare Research and Quality (US).

12. Ayoubkhani D, Khunti K, Nafilyan V, Maddox T, Humberstone B, et al. (2021) Epidemiology of postCOVID syndrome following hospitalisation with coronavirus: a retrospective cohort study. BMJ 372: 693.

13. Nisen M, He E (2020) Covid Everlasting. Bloomberg Opinion.

14. Nalbandian A, Sehgal K, Gupta A, Madhavan MV, McGroder, et al. (2021) Post-acute COVID-19 syndrome. Nat Med 27: 601-615.

15. National Institute for Health and Care Excellence (2020) COVID-19 rapid guideline: managing the long-term effects of COVID-19.

16. Rey Calero J (1989) Epidemiological method and community health. Madrid: Interamericana. McGrawHill.

17. Strategy for early detection, surveillance and control of

\section{Epidemiology International Journal}

COVID-19. Ministry of Health. Spain pp: 1-32.

18. Mayor N, Tsang R, Joy M, Hobbs FR, de Lusignan S (2021) Long covid: coding is caring. BMJ 373: 1262.

19. Turabian JL (2021) Post-Acute Covid-19 in General Medicine: A Clinical-Epidemiological Reporting of 33 Patients from March 2020 to March 2021 in Toledo (Spain). Epidemol Int J 5(1): 000S1-018.

20. Strauss AL (1984) Chronic illness and the quality of life. St Louis: The C.V. Mosby Company.

21. WHO (2019) International Statistical Classification of Diseases and Health-Related Problems. ICD-10 Version.

22. Royal Collage of General Practitioners (1986) The Classification and Analysis of General Practice Data. In: $2^{\text {nd }}(E d n),. p p: 125$.

23. Donaldson RJ, Donaldson LJ (1983) Essential Comunity Medicine. Lancaster: MTP Press.

24. Turabian JL (2017) Family Genogram in General Medicine: A Soft Technology that can be Strong. An Update. Res Med Eng Sci 3(1): 186-191.

25. Russell LT (2020) Capturing Family Complexity in Family Nursing Research and Practice. J Fam Nurs 26(4): 287293.

26. Watts C, Shrader E (1998) How to do (or not to do)... The genogram: a new research tool to document patterns of decision-making, conflict and vulnerability within households. Health Policy Plan 13(4): 459-464.

27. Mcllvain H, Crabtree B, Medder J, Stange KC, Miller WL (1998) Using practice genograms to understand and describe practice configurations. Fam Med 30(7): 490496.

28. Mao S, Huang T, Yuan H, Li M, Huang X, et al. (2020) Epidemiological analysis of 67 local COVID-19 clusters in Sichuan Province, China. BMC Public Health 20: 1525.

29. Turabian JL (2017) Prevalence of Chronic Diseases: in Defence of Epidemiological Craftsmanship in Family Medicine. CP Epidemiology 1(1): 005.

30. Turabian JL, Ruiz SM, Jove RC (2016) Epidemiology in Family Medicine. J Gen Pract (Los Angel) 4: 278.

31. Turabian JL (2018) The Varieties of the Epidemiological Experiences and the Contribution of the General Physician. J Community Prev Med 1(2): 1-5.

32. Turabian JL (1995) Notebooks of Family and Community Medicine. An introduction to the principles of Family 


\section{Epidemiology International Journal}

Medicine. Madrid: Díaz de Santos.

33. Poenaru S, Abdallah SJ, Medina VC, Cowan J (2021) COVID-19and post-infectiousmyalgicencephalomyelitis/ chronic fatigue syndrome: a narrative review. Ther $\mathrm{Adv}$ Infect Dis 8: 1-16.

34. Jahdhami IA, Naamani KA, Mawali AA (2021) The Postacute COVID-19 Syndrome (Long COVID). Oman Med J 36(1): 220.

35. Kron T (2021) Long-COVID: Infectiously recovered, but not healthy - at least every 10th patient suffers from these long-term consequences. Medscape.

36. Davis HE, Assaf GS, McCorkell L, Wei H, Low RJ, et al. (2020). Characterizing Long COVID in an International Cohort: 7 Months of Symptoms and Their Impact. MedRxiv pp: 1-70.

37. Sigfrid L, Drake TM, Pauley E, Jesudason EC, Olliaro $P$, et al. (2021) Long Covid in adults discharged from UK hospitals after Covid-19: A prospective, multicenter cohort study using the ISARIC WHO Clinical Characterization Protocol. MedRxiv pp: 1-42.

38. Sudre CH, Murray B, Varsavsky T, Graham MS, Penfold RS, et al. (2020) Attributes and predictors of long-covid: analysis of covid cases and their symptoms collected by the Covid Symptoms Study App. MedRxiv.

39. Carfi A, Bernabei R, Landi F (2020) Post-Acute Care Study Group. Persistent Symptoms in Patients after Acute COVID-19. JAMA 324(6): 603-605.

40. Pereira C, Harris BHL, Giovannantonio MD, Rosadas C, Short CE, et al. (2021) The Association Between Antibody Response to Severe Acute Respiratory Syndrome Coronavirus 2 Infection and Post-COVID-19 Syndrome in Healthcare Workers. J Infect Dis 223(10): 1671-1676.

41. Huang C, Huang L, Wang Y, LiX, Ren L, etal.(2021) 6-month consequences of COVID-19 in patients discharged from hospital: a cohort study. Lancet 397(10270): 220-232.

42. Havervall S, Rosell A, Phillipson M, Mangsbo SM, Nilsson P, et al. (2021) Symptoms and functional impairment assessed 8 months after mild COVID-19 among health care workers. JAMA 325(19): 2015-2016.

43. Leon SL, Ostrosky TW, Perelman C, Sepulveda R, Rebolledo PA, et al. (2021) More than 50 Long-term effects of COVID-19: a systematic review and metaanalysis. MedRxiv pp: 1-22.

44. Leung TYM, Chan AYL, Chan EW, Chan VKY, Chui CSL, et al. (2020) Short- and potential long-term adverse health outcomes of COVID-19: a rapid review. Emerg Microbes Infect 9(1): 2190-2199.

45. Dennis A, Wamil M, Kapur S, Alberts J, Badley AD, et al. (2020) Multi-organ impairment in low-risk individuals with long COVID. MedRxiv pp: 1-23.

46. Lambert N, El Azab SA, Ramrakhiani NS, Barisano A, Yu $\mathrm{L}$, et al. (2021) COVID-19 survicors reports of the timing, duration, and health impacts of post-acute sequelae of SARS-CoV2 (PASC) infection. MedRxiv pp: 1-23.

47. Nasserie T, Hittle M, Goodman SN (2021) Assessment of the frequency and variety of persistent symptoms among patients with COVID-19: A systematic review. JAMA Netw Open 4(5): 2111417.

48. Taquet M, Geddes JR, Husain M, Luciano S, Harrison PJ (2021) 6-month neurological and psychiatric outcomes in 236379 survivors of COVID-19: a retrospective cohort study using electronic health records. Lancet Psychiat 8(5): 416-27.

49. Sivan M, Rayner C, Delaney B (2021) Fresh evidence of the scale and scope of long covid. BMJ 373: 853.

50. Meinhardt J, Radke J, Dittmayer C, Franz J, Thomas C, et al. (2021) Olfactory transmucosal SARS-CoV-2 invasion as a port of central nervous system entry in individuals with COVID-19. Nat Neurosci 24(2): 168-175.

51. Marx V (2021) Scientists set out to connect the dots on long COVID. Nat Methods 18: 449-453.

52. Cotelo J (2021) Post-COVID-19 syndrome: rebound in neuropsychiatric disorders is predicted. Medscape.

53. Daniali H, Flaten MA (2021) Experiencing COVID-19 symptoms without the disease: The role of nocebo in reporting of symptoms. Scand J Public Health pp: 1-9.

54. Berry P (2021) Use patient reported outcome measures (PROMs) in treatment of long covid. BMJ 373: 1260.

55. Mandrola JM (2021) Why Long COVID Worries Me. Medscape.

56. Viciano A (2021) "As if Corona had eaten my brain": This doctor has long COVID - how the disease changed her life and how she deals with uncertainty. Medscape.

57. Greenhalgh T, Knight M, A'Court C, Buxton M, Husain L (2020) Management of post-acute covid-19 in primary care. BMJ 370: 3026.

58. Maxwell E (2020) Themed review: living with covid19. National Institute for Health Research pp: 1-29. 


\section{Epidemiology International Journal}

59. Pérez OM, Merino E, Leon Ramirez JM, Andres M, Ramos JM, et al. (2021) Post-acute COVID-19 syndrome. Incidence and risk factors: A Mediterranean cohort study. J Infect 82(3): 378-383.

60. Duarte ÁR, Izquierdo MR, Guerrero Fernández de Alba I, Contreras MP, Martínez NFF, et al. (2021) Sequelae, persistent symptomatology and outcomes after COVID-19 hospitalization: the ANCOHVID multicentre 6-month follow-up study. BMC Med 19: 129.

61. Huang L, Cao B (2021) Post-acute conditions of patients with COVID-19 not requiring hospital admission. Lan Infect Dis pp: 1-2. 